\title{
Literature for Africa in French and Portuguese
}

THE International Committee on Christian Literature for Africa has collected information about literature recently published, or awaiting publication, in the French and Portuguese languages. The Committee is prepared to send specimen copies of such publications to selected correspondents in the areas concerned. French publications may be obtained in the Congo from La Librairie des Missions Évangéliques, Leopoldville; Portuguese publications must be ordered from the Centro Cooperação Cristã, Rua do Ataide 5, r/c Lisbon, Portugal.

\section{Interterritorial Language (Swahili) Committee}

IN the report of the Inter-territorial Language Committee for 1943 , lately received, it is stated that 1o new works were published during the year and the manuscripts of 28 others were submitted for perusal. Four other translations were made by the secretariat staff. For the Essay Competition there were 21 s entries, an increase of 93; these were all African, none being received, as in the previous year, from European schools. A high standard was revealed in the essays, and it is particularly interesting to learn that Africans on military service in distant fields were among the competitors. Thirty-one scripts were submitted in the Authorship competition and eight of these were considered by the judges to be of very considerable merit. The prize was awarded to A. O. M. Makame of Tabora, whose manuscript, The East African in the Modern World, was adjudged to be an original and independent contribution. The Committee express the opinion that, with one or two exceptions, the manuscripts submitted give evidence of a developing gift of authorship.

\section{International Labour Office}

THE Governing Body of the I.L.O., at its meeting in London on 3x January r945, decided to create a Committee on Social Policy in Dependent Territories to advise the Office on the principles to be observed in the treatment of problems of social policy in dependent territories. The Committee will be composed of twelve independent members and three Governing Body members.

\section{CONTRIBUTORS TO THIS NUMBER}

J. Ronin, Administrateur Adjoint des Colonies, A.O.F., Gouvemement de Sénégal.

E. E. Evans-Pritchard, Formerly Research Lecturer in African Sociology in the University of Oxford; at present serving with H.M. Forces; Author of Witchcraft, Oracles and Magic, Oxford, 1937, The Nwer, Oxford, 1940, and numerous papers on witchcraft, sorcery, kinship, \&c.; joint editor with $M$. Fortes of African Political Systems, Oxford, 1940.

Kwame Frimpong, Twi announcer, Gold Coast Information Service. 